\title{
ÚSTAVNÍ RÁMEC ZAJIŠŤOVÁNÍ BEZPEČNOSTI ČESKÉ REPUBLIKY - ZHODNOCENÍ SOUČASNÉHO STAVU A ÚVAHY DE LEGE FERENDA*
}

\author{
JAN KUDRNA
}

\begin{abstract}
The Constitutional Frame of Ensuring of the Security in the Czech Republic An Evaluation of the Current State and a Reflection of Possible Changes

The presented article is dedicated to the constitutional regulation of the security issues in the Czech Republic. The article focuses especially on the art. 43 of the Czech Republic Constitution. It analyses the applicability of the sections, which were not applied yet, and real application of the sections, which are applied regularly as well. Firstly the issue of declaring the state of war is described, with the stress on problems which could appear in case of emergency under pressure of lacking time or attack on the Czech Republic. Later there is described the issue of sending armed forces of the Czech Republic abroad, especially with the obligation to the NATO and its VJTF forces. Special attention is given to the constitutional regulation of the flights of foreign armed forces over the territory of the Czech Republic and their authorisation. This procedure is in fact inapplicable, as is evident from analysis of the practice. The article deals also with a hypothetic issue of establishing foreign military base at the territory of the Czech Republic and its authorisation. In every above mentioned area there is proposed also possible legal solution de lege ferenda.
\end{abstract}

Keywords: constitution, Czech Republic, security, NATO, VJTF, flights, transfers, armed forces

Klíčová slova: ústava, Česká republika, bezpečnost, NATO, VJTF, přelety, průjezdy, ozbrojené síly

DOI: $10.14712 / 23366478.2017 .29$

\section{I. ÚVODEM}

Jedním z hlavních a tradičních úkolů státu je zajištění bezpečí pro své obyvatelstvo. Každý stát plní bezpečnostní funkci a lze říci, že toto je také jeden z důvodů vedoucích ke zřizování států. Bezpečím lze rozumět absenci ohrožení. Ohrožení mohou být mnoha druhů a pojem bezpečnosti můžeme chápat $\mathrm{v}$ širším a užším slova smyslu.

V širším slova smyslu by se jednalo o zajištění také napřs. sociálně nebo environmentálně bezpečného prostředí, v němž by jednotlivec nebyl vystaven nouzi nebo ohrožení života a zdraví pocházejícímu ze znečištěného životního prostředí.

\footnotetext{
* Tento článek byl vypracován v rámci programu PROGRES Q04. Autor je odborným asistentem na katedře ústavního práva Právnické fakulty Univerzity Karlovy.
} 
V užším slova smyslu, jak bývá pojem bezpečnosti často vykládán, se jedná o zajištění nerušené existence státu, včetně zachování jeho svrchovanosti a územní celistvosti, spolu se stabilitou stávajícího politického režimu, což jsou základní předpoklady pro funkčnost státu a naplňování jeho dalších úkolů, kterými může být zajišt'ování veřejného pořádku a bezpečnosti uvnitř státu, včetně ochrany života, zdraví a majetku jeho obyvatel.

S ohledem na to, že každý stát je členem mezinárodního společenství, má zajišt’ování bezpečnosti státu také mezinárodně politický a mezinárodně právní aspekt. Pojem svrchovanosti není vlastní pouze ústavněprávní či státoprávní teorii, ale má svůj odraz také v mezinárodním právu veřejném a jeho pramenech. Např. Charta Organizace spojených národů (dále jen „OSN“) ve svém čl. 2 uvádí jako první zásadu, na které je OSN postavena, zásadu svrchované rovnosti všech svých členů. Ve svém čl. 51 potom zaručuje právo na individuální nebo kolektivní sebeobranu svých členů.

$\mathrm{V}$ př́ípadě bezpečnosti státu je velmi dobře patrné propojení jejích vnějších a vnitřních aspektů. Ohrožení státu může přijít zvenčí a ovlivnit podmínky uvnitř státu, stejně jako změna vnitřních poměrů může mít vliv na část nebo dokonce celé mezinárodní společenství.

Zde jsou důvody pro konstitucionalizaci, tedy ústavní zakotvení a regulaci otázek zajištění bezpečnosti. Prvý důvod spočívá v úzké vazbě mezi ústavním pojmem svrchovanosti a jejím zajištováním. Jestliže svrchovanost státu je ústavní hodnotou, potom by na stejné úrovni měl být stanoven alespoň základní rámec jejího zajišstování.

Druhým argumentem ve prospěch konstitucionalizace otázek zajištování bezpečnosti je již výše zmíněná úzká souvislost se životem mezinárodního společenství a nakonec také pravidly mezinárodního práva veřejného. Ústavní zakotvení v tomto smyslu znamená v př́ípadě ústavních států jednak předvídatelnost, jednak snazší kontrolu využívání napřr. ozbrojených sil a ozbrojených sborů, at' už navenek anebo uvnitř státu. Tato skutečnost nabývá na dalším významu v období internacionalizace lidských práv, kdy tato přestávají být do značné míry vnitřní záležitostí státu a stávají se jednou z hodnot ovlivňujících činnost mezinárodního společenství.

Třetím důvodem pro ústavní zakotvení základních pravidel zajišt’ování bezpečnosti státu a jeho obyvatel je to, že zajišt'ování bezpečnosti s sebou ve větší nebo menší míře nese omezování lidských práv a svobod. Ta jsou přitom zakotvena na ústavní úrovni a jsou jedním z hybných momentů vytvoření ústavy jako společenské smlouvy a nástroje sloužícího ochraně lidských práv a svobod před nepřiměřenými zásahy veřejné moci. Zde tedy platí, že změny a omezení v této klíčové otázce moderního konstitucionalismu by měly být prováděné nástrojem stejné právní síly a společenského významu, jako byly založeny.

Konečně čtvrtý důvod hovořící pro konstitucionalizaci otázek zajišt’ování bezpečnosti spočívá v tom, že v některých případech je hrozící nebezpečí tak velké, že běžné prostředky, jimiž disponuje veřejná moc, nejsou dostačující. V takových př́ípadech je nezbytné použít prostředků mimořádných, které kromě dočasného omezení některých lidských práv a svobod vyžadují v zájmu efektivní činnosti také zjednodušení pravidel řídících konání veřejné moci. To znamená modifikaci systému dělby zakotveného opět na ústavní úrovni. I v tomto př́ípadě platí, že ke změně je nutné použít prostředek stejné právní síly. Protože uspořádání a dělba veřejné moci je druhou základní záležitostí defi- 
nující moderní konstitucionalismus, i v tomto př́padě je nutná ústavní úprava pravidel a nástrojů, jimiž lze do systému dělby moci zasáhnout.

Pro stanovení ústavního rámce zajišt’ování bezpečnosti státu tedy hovoří to, že velmi úzce souvisí s ústavními pojmy svrchovanosti státu a podílení se na životě mezinárodního společenství, a dále s pojmy a zajištěním lidských práv a základních svobod a systému dělby moci. Pro zajišt'ování bezpečnosti je typické to, že v řadě případů v zájmu odstranění nebezpečí je nutno sáhnout k prostředkủm, které samy o sobě mohou některé uvedené hodnoty ohrozit, respektive na nějakou dobu suspendovat. Každý zásah do nich by měl mít vzhledem $\mathrm{k}$ jejich klíčovému významu stejnou legitimační a legální základnu, jako ony samy.

Moderní ústavy, hledající vyváženou cestu mezi zajištěním bezpečnosti obyvatel a státu na straně jedné a zajištěním demokracie a právního státu na straně druhé, obvykle obsahují pravidla předem stanovící meze zásahů do ústavně garantovaných práv a svobod, dále ustanovení modifikující způsob vytváření veřejné vůle a její aplikace a kontroly, a to vše včetně kontrolních mechanismů, které musí v kterémkoliv okamžiku umožňovat ukončení mimořádného právního stavu orgánem odlišným od toho, který rozhodl nebo inicioval jeho vyhlášení.

Koncepční potřeba zakotvit a limitovat mimořádné právní stavy na ústavní úrovni se objevuje s počátkem konstitucionalismu. Tento právně filozofický směr vychází z předpokladu svobody jednotlivce, přičemž stát je ustavován za účelem její ochrany. Proto má být stát omezený a kontrolovaný, aby nedošlo ke zneužití moci a především zbavení obyvatel svobody. Potom ovšem musí nutně nastat problém, jak na jedné straně zajistit dostatečné nástroje $\mathrm{k}$ udržení a obnově veřejného pořádku a bezpečnosti i v mimořádných situacích, a jak na straně druhé dosáhnout toho, aby se dočasná mimořádná situace nestala trvalou. Jinými slovy, aby svobody těžce vydobyté na panovníkovi, často absolutistickém, nebyly opět odstraněny ve jménu nutnosti obnovit bezpečnost státu. $\mathrm{Z}$ toho důvodu je saháno ke konstitucionalizaci, ${ }^{1}$ parlamentarizaci, ${ }^{2}$ diferenciaci, a s ní spojené proporcionalizaci $i^{3}$ mimořádných právních stavů.

1 Tento pojem použivám ve smyslu konstitucionalistickém, jak je popsán výše a jak jej používá také např. polský konstitucionalista prof. Leszek Garlicki. Viz např. GARLICKI, L.: Polskie prawo konstytucyjne (zarys wykładu). 4. vyd. Warszawa: Liber, 2000, s. 418. Lze se setkat také s použitím tohoto pojmu ve smyslu čistě instrumentálním, kdy se konstitucionalizací rozumí účelové zakotvení (často již uskutečňovaných) mimořádných pravomocí exekutivy do textu ústavy $\mathrm{v}$ tom rozsahu, $\mathrm{v}$ jakém je to pro exekutivu výhodné. Viz např. LEE, H. P.: Constitutionalised emergency powers: a plague on Asian constitutionalism? In RAMRAJ, V. V. - THIRUVENGADAM, A. K. (eds.): Emergency Powers in Asia: Exploring the Limits of Legality. Cambridge: Cambridge University Press, 2009, s. 399. Takové použití uvedeného pojmu však považuji za zavádějící, protože hodnotově vyprazdňuje samotný pojem „konstitucionalismus“ a nakonec vede k tomu, že pojem „legitimita“ je redukován na „legalitu“. Toto odlišné užívání jednoho pojmu nicméně dobře ukazuje na rozdíl mezi evropskou, potažmo západní ústavností a situací v některých státech Asie.

2 Obdobné upozornění lze uvést také v tomto př́ípadě. Ve smyslu konstitucionalistickém je předpokládána existence svobodného a samostatného parlamentu, který je schopen vykonávat kontrolu nad výkonnou mocí. Ve druhé citované publikaci je naopak hovořeno o exekutivě, která využívá svou kontrolu nad parlamentem.

3 Viz jejich vyjádření např. v čl. 4 odst. 1 Mezinárodního paktu OSN o občanských a politických právech z roku 1966, kde se hovoří o „rozsahu, který si vyžádají potřeby takové situace“. Obdobně také evropská Úmluva o ochraně lidských práv a základních svobod ve svém čl. 15, který stanoví „, rozsahu př́sně vyžadovaném naléhavostí situace“. 
Konstitucionalizace, neboli definice na ústavní a nikoliv zákonné úrovni, znamená určitou stabilizaci pravidel za předpokladu, že se jedná o ústavu rigidní. Současně to znamená, že ústavní pravidla jako záruky lidských práv a svobod nebo pravidla dělby a kontroly moci jsou suspendována předpisem stejné právní síly, jako byla ustavena.

Parlamentarizace, neboli svěření vyhlašování nebo přinejmenším rušení mimořádných opatření do rukou parlamentu zajišt’uje kontrolu nad exekutivou, která v mimorádných situacích posiluje a je částečně osvobozována zpod kontroly. Znamená to také vyšší legitimitu rozhodnutí, nebot' parlament je reprezentativnější orgán než vláda.

Diferenciace a proporcionalizace má za cíl minimalizovat zásah do ústavně garantovaných práv a svobod, respektive mechanismů dělby a kontroly moci. Zasahováno má být pouze v nezbytně nutné míře a způsobem odpovídajícím charakteru ohrožení. Mimořádná opatření mají být ultima ratio.

Cílem těchto ustanovení je předem a transparentně určit jasná pravidla fungování státu a společnosti, spolu s definováním postavení jednotlivce, pro jednotlivé mimořádné situace znamenající ohrožení bezpečnosti. Pouze takto nepochybně a jasně stanovená pravidla mohou později v krizové situaci umožnit snadnou kontrolu, zda nedochází ke zneužívání moci.

Není nezbytně nutné, aby všechna tato pravidla byla předem stanovena a kodifikována. Je však žádoucí, aby byl předem stanoven jasný rámec, který nebude dvojznačný a o kterém bude zřejmé, že je při dodatečném určování pravidel nepřekročitelný. Je tedy možné přijmout dodatečnou úpravu ve stavu hrozící krize, prrípadně i v jejím průběhu. Mělo by však být předem jasné, čeho se daná úprava týkat může a které meze jsou nepřekročitelné.

$\mathrm{Z}$ hlediska, jak jednotlivé státy $\mathrm{k}$ této problematice přistupují, můžeme hovořit o dvou základních skupinách států.

Do jedné patří státy, které problematiku zajišt’ování bezpečnosti řeší na ústavní úrovni, a to velmi podrobně. Důvodem může být špatná historická zkušenost se zneužitím státní moci, často za účelem obnovení bezpečnosti státu a jeho obyvatel. Do této kategorie patří např. Německo, Španělsko nebo Polsko. Tyto státy stanoví ve svých ústavách relativně podrobná pravidla pro použití mimořádných opatření a jasné meze pro omezení ústavně garantovaných lidských práv a svobod, respektive pro omezení běžného systému dělby moci. Lze říci, že v řadě případů tyto státy v zásadních otázkách zajišt'ování bezpečnosti ponechávají velmi malý prostor zákonodárci.

Do druhé skupiny patří státy, které podobnou historickou zkušenost nemají, případně jejich postavení je takové, že mají důvod předpokládat, že riziko některých druhů ohrožení je v jejich prrípadě spíše malé. Tyto státy často mají pouze velmi rámcovou nebo dokonce žádnou ústavní úpravu bezpečnostních záležitostí a vycházejí z toho, že v případě potřeby bude dostačující úprava na úrovni zákona. Zde je řeč napřr. o Spojených státech amerických, Británii nebo Švýcarsku.

Z tohoto hlediska může být zajímavé přemýšlet o ústavní úpravě a jejím vývoji v České republice. Ačkoliv Česká republika patři svými zkušenostmi do výše uvedené prvé skupiny států, protože se v rámci kontinuity s Československem setkala jednak se zneužitím moci proti ústavně garantovaným právům a svobodám, jednak s opakovanou cizí okupací, včetně potíží se zajištěním činnosti a kontinuity státních orgánů v exi- 
lu, její ústavní úprava tyto zkušenosti nereflektuje podobným způsobem, jako je tomu v př́padě některých sousedních zemí s podobnou zkušeností. Zejména po prvních pět let své existence Česká republika odpovídala svým charakterem druhé uvedené skupině států. Nyní, jak bude ukázáno dále, jsou výše uvedené zásady částečně naplněny, ale právní úprava není komplexní a není v některých směrech zcela funkční.

\section{SOUČASNÁ ÚSTAVNÍ ÚPRAVA ZAJIŠŤOVÁNÍ BEZPEČNOSTI A JEJÍ ZHODNOCENÍ}

\section{NEDU゚SLEDNÁ KONSTITUCIONALIZACE}

Vůči stávající ústavní úpravě lze vznést jistou námitku koncepčního charakteru. Již na počátku jsem odkázal na stávající trendy konstitucionalistického řešení zakotvení a regulace mimořádných právních stavi̊, projevující se v zásadách jejich konstitucionalizace, parlamentarizace, diferenciace a proporcionalizace.

V případě České republiky nelze říci, že by všechny uvedené zásady byly naplněny odpovídajícím způsobem. Především konstitucionalizace mimořádných právních stavů není důsledná. V prvé řadě proto, že ústavní úprava je v př́ípadě stavu válečného a stavu ohrožení státu spíše kusá, nebo dokonce nejasná. V druhé řadě proto, že ústavní úprava není výlučná. Vedle tř́i mimořádných právních stavů, které předpokládají předpisy ústavního pořádku, existuje ještě stav čtvrtý, a sice stav nebezpečí vyhlašovaný podle § 3 zákona č. 240/2000 Sb. o krizovém řízení a o změně některých zákonů, v platném znění (dále jen ,krizový zákon“).

Tento čtvrtý mimořádný právní stav se přitom svou podstatou nijak neodlišuje od tří mimořádných právních stavů definovaných na ústavní úrovni. Dokladem zde může být rozsah opatření, která může podle $\S 6$ krizového zákona v př́ípadě nouzového stavu vyhlásit vláda, a rozsah opatření, která podle § 14 téhož zákona může nařídit hejtman kraje. Přirozeně existuje rozdíl kvantitativní, ale nikoliv zásadní rozdíl kvalitativní.

Závěr v tomto směru může být takový, že ústavní úprava mimořádných právních stavů není limitem pro rozšiřování jejich katalogu zákonodárcem. Tato situace z hlediska konstitucionalismu má daleko k ideálu. Nelze jistě popř́ít její praktičnost, avšak zásady konstitucionalismu směřují ke kontrole státní moci, nikoliv k usnadnění jejího rozšiřování a pružného uplatňování, za cenu pružného omezování lidských práv. Stojí za to připomenout, že právo státu na sebeobranu a jeho právo i povinnost zajišt'ovat také vnitřní pořádek, nikdy nebylo ani teoreticky zpochybňováno. Bylo vždy vnímáno jako součást práva státu na sebezachování. Konstitucionalismus však směřuje k omezení arbitrárního uplatňování a rozšiřování státní moci na úkor svobod jednotlivce.

Konstitucionalizace bezpečnostních otázek zejména ve vztahu k ústavně garantovaným právům a svobodám je v České republice problematická také proto, že velká většina ústavně garantovaných práv ke své realizaci bud' potřebuje zákon, nebo může být zákonem omezena z ústavně stanovených důvodů. Všude tam, kde jsou mezi důvody uváděny ochrana veřejného pořádku, bezpečnosti nebo bezpečnosti státu, lze ústavně garantovaná práva omezit zákonem v př́ípadě mimořádné situace, za účelem jejíhož 
odstranění je vyhlašován mimořádný právní stav. To však znamená, že z hlediska Listiny je dostatečné zakotvení mimořádného právního stavu na zákonné úrovni, respektive z hlediska Listiny ani nemusí být mimořádný právní stav vyhlašován a na základě zákona může být přijato za formálně „,běžné“ situace, avšak za stavu faktického mimořádného ohrožení, pouze dílčí mimořádné opatření.

Jinými slovy, nedostatečná konstitucionalizace v případě České republiky znamená, že k prrijímání mimořádných opatření spočívajících v omezování ústavně garantovaných práv a ukládání povinností není ústavní zakotvení, případně vyhlášení mimořádného právního stavu nutné.

Další dvě zásady, tedy proporcionalizace a diferenciace jsou v zásadě naplněny, ačkoliv, jak bude ukázáno dále, není zcela jasné, co je podstatou jednoho z mimořádných právních stavů. Zásada parlamentarizace je naplněna, nicméně až př́liš, jak bude ukázáno také dále.

Ústavní zakotvení mimořádných právních stavů, jak k nim došlo zejména přijetím ústavního zákona č. 110/1998 Sb., tak má především význam pro zavedení mechanismů zpružnění a zjednodušení činnosti ústavních orgánů.

\section{NEJASNOST A NEÚPLNOST ÚSTAVNÍ ÚPRAVY VÁLEČNÉHO STAVU}

Zaměříme-li se na konkrétní právní úpravu a její formulace, potom je třeba s ohledem na její strukturu na prvním místě věnovat pozornost otázce ústavní úpravy válečného stavu. V Ústavě je zmíněn dvakrát $-\mathrm{v}$ čl. 43 odst. 1 a v čl. 39 odst. 3 . Prvé ustanovení určuje, kdy může být válečný stav vyhlášen a kým. Druhé určuje proceduru.

Válečný stav je tedy vyhlašován parlamentem, je-li Česká republika napadena nebo je-li třeba plnit mezinárodní smluvní závazky o společné obraně proti napadení. K vyhlášení je třeba nadpoloviční většiny všech členů obou komor parlamentu. Tolik, co je z ústavní úpravy zřejmé.

Co však zřejmé není, je otázka, co se vlastně válečným stavem rozumí. V úvahu přicházejí dvě možnosti. Bud’ se může jednat o vyhlášení války ve smyslu stavu ozbrojeného konfliktu mezi státy z hlediska mezinárodního práva veřejného, anebo se může jednat o mimořádný právní stav mající vnitrostátní účinky v době, kdy se stát nachází ve válce. Na tuto pojmovou nejasnost upozorňuje ostatně odborná literatura. ${ }^{4}$ Není to zcela jasné ani z informačních internetových stránek státních institucí. ${ }^{5}$

Zcela otevřená a jak českým právním řádem, tak i teorií je neřešená skutečnost, na kterou poukazuje odborná literatura v zahraničí, že válečný stav znamená mimo jiné

4 Více v této věci viz např.: HŘEBEJK, J.: Válečný stav. In PAVLÍČEK, V. - JIRÁSKOVÁ, V. (eds.): Bezpečnost České republiky a potřeba ústavnich změn. Praha: UK Právnická fakulta, 2004 nebo JIRÁSEK, J. Vyhlašování mimořádných stavů. In PAVLÍČEK, V. - JIRÁSKOVÁ, V. (eds.): Bezpečnost České republiky a potřeba ústavnich změn. Praha: UK Právnická fakulta, 2004.

5 Zde Ministerstva vnitra České republiky: http://www.mvcr.cz/clanek/valecny-stav.aspx [cit. 20. 10. 2016]. Na citované stránce se hovoří o stavu vzniklém mezi zneprátelenými stranami vypuknutím ozbrojeného konfliktu, a to bez ohledu na to, zda byla vypovězena válka. Zdůrazněna je tedy faktičnost onoho stavu. To je dále potvrzeno odkazem na Ústavu, v němž se hovoří o situaci, kdy je Česká republika napadena nebo musí plnit své závazky týkající se společné obrany proti napadení. Tedy má se jednat o faktický existující stav, na který parlament reaguje vyhlášením válečného stavu. 
také převzetí výkonu části veřejné správy vojenskými orgány, včetně např. podřízení civilistů vojenskému soudnictví. ${ }^{6}$

Provést výklad v této otázce je složité, a žádný výklad dle mého názoru nevede ke zcela jednoznačnému závěru. Osobně se kloním k výkladu, že válečným stavem ve smyslu stávající ústavní úpravy je míněn zvláštní mimořádný právní stav mající vnitrostátní účinky na ústavní uspořádání ve všech směrech, jak byly výše popsány. K tomu mě vede následující úvaha.

Zaprvé válečný stav jako mimořádný právní stav s vnitrostátními účinky je znám jak teorii a odborné literaturěe ${ }^{7}$, tak i jiným ústavním úpravám. ${ }^{8}$ Zadruhé z formulace Ústavy vyplývá, že válečný stav je vyhlašován $v$ okamžiku, kdy už se stát nachází ve válečném konfliktu ve smyslu mezinárodního práva veřejného, tedy mu byla válka vyhlášena, respektive konflikt již fakticky probíhá. Př́ípadně se totéž týká jeho smluvního spojence, což má nakonec stejné důsledky. Zatřetí, pokud by bylo třeba vyhlásit válku ve smyslu mezinárodního práva veřejného, může tak zřejmě učinit na základě norem tohoto práva hlava státu, přičemž z hlediska ústavního práva České republiky tato pravomoc zřejmě spadá pod ustanovení čl. 63 odst. 1 písm. a) Ústavy. Začtvrté lze jako podpůrný argument - podpůrný proto, že se nejedná o interpretaci Ústavy - uvést skutečnost, že $\mathrm{s}$ válečným stavem jako druhem mimořádného právního stavu pracuje zákonodárce, a to např. v zákoně č. 241/2000 Sb. o hospodářských opatřeních pro krizové stavy a o změně některých souvisejících zákonů, v platném znění. ${ }^{9}$

Naproti tomu výklad ve smyslu, že válečným stavem podle čl. 43 Ústavy se rozumí deklarace stavu války dle mezinárodního práva veřejného, narazí na všechny výše uvedené argumenty. Vedle toho se musí vypořádat s problémem, že pro úspěšnou, legální aktivizaci všech vnitrostátních opatření pro dobu války by parlament musel hlasovat dvakrát. Jednou o vyhlášení válečného stavu ve smyslu mezinárodního práva veřejného, podruhé pro vyhlášení zrèejmě stavu ohrožení státu, který by mohl vést k některým vnitrostátním účinkům, ale který např. neumožňuje provést mobilizaci.

Přijmeme-li výše uvedené závěry o tom, že válečný stav je jedním ze tří ústavně definovaných mimořádných právních stavů v České republice, budou některé otázky vyřešeny.

Některé však zůstanou otevřeny, a to např. otázka, na čí podnět může parlament válečný stav vyhlásit. $V$ tomto směru jak ústavní, tak zákonná úprava mlčí. Patrně by se tak mělo dít na návrh vlády. Pro tento závěr hovoří jednak skutečnost, že za zajištění obranyschopnosti státu je odpovědná vláda. ${ }^{10}$ Dále je to vláda, respektive jednotlivá ministerstva, typicky ministerstvo zahraničních věcí a ministerstvo obrany, které jsou vybaveny pravomocemi a nástroji $\mathrm{k}$ tomu, aby mohly podat jasnou informaci o tom, zda nastala jedna ze dvou situací předpokládaných čl. 43 odst. 1 Ústavy, za nichž může být

\footnotetext{
6 V této věci viz např.: BRZEZIŃSKI, M.: Stany nadzwyczajne w polskich konstytucjach. Warszawa: Wydawnictwo Sejmowe, 2007, s. 36.

7 Viz např. předchozí poznámka pod čarou.

8 Viz např. čl. 228 odst. 1 Ústavy Polské republiky z 2. dubna 1997.

9 Viz ustanovení § 1 odst. 1 citovaného zákona.

10 Viz ustanovení § 4 zákona č. 222/1999 Sb. o zajišt’ování obrany České republiky, v platném znění.
} 
válečný stav parlamentem vyhlášen. Podpůrně lze v tomto výkladu použít také analogii k vyhlašování stavu ohrožení státu, kde je jako iniciátor určena jednoznačně vláda. ${ }^{11}$

Nejasnosti spojené s aktuální právní úpravou válečného stavu lze tedy snad překlenout výkladem. Určité výhrady však lze mít ke způsobu vyhlašování válečného stavu. Stávající mechanismus vyžaduje rozhodnutí parlamentu učiněná v obou komorách nadpoloviční většinou všech jejich členů. Tento mechanismus se za určitých okolností může ukázat jako poměrně těžkopádný, zejména pokud by nastala časová tíseň. Je vhodné upozornit, že celá řada opatření pro zajištění obrany státu je vázána na formální vyhlášení válečného stavu, a bez něj není možná jejich legální realizace. Může se jednat o všeobecnou mobilizaci, která je vázána na vyhlášený válečný stav ${ }^{12}$, nebo o některých hospodářských opatřeních, která jsou také vázána na vyhlášený válečný stav. ${ }^{13}$

Ačkoliv tedy vyhlašování válečného stavu v rámci našeho ústavního systému plně odpovídá výše popsanému požadavku parlamentarizace, stálo by za úvahu počítat s náhradním způsobem vyhlášení válečného stavu v př́padě, že by hrozilo časové prodlení než by se parlament sešel. Taková situace může nastat v př́padě probíhající agrese proti státu nebo v př́padě, že taková hrozba bezprostředně hrozí. Náhradní způsob, jak je ostatně znám také jiným ústavním úpravám, ${ }^{14}$ by mohl spočívat ve vyhlášení válečného

11 Viz čl. 7 odst. 1 ústavního zákona č. 110/1998 Sb. o bezpečnosti České republiky, v platném znění.

12 Viz ustanovení $§ 23$ odst. 3 zákona č. 585/2004 Sb. o branné povinnosti a jejím zajištování, v platném znění.

13 Viz ustanovení § 23 zákona č. 241/2000 Sb. v platném znění.

14 Již zmíněná polská ústavní úprava dokonce počitá s vyhlašováním válečného stavu prezidentem republiky na návrh Rady ministrů jako se standardním způsobem. Ústava Estonské republiky z 28. června 1992 ve svém $§ 128$ odst. 2 dává prezidentu republiky v př́ipadě agrese proti republice vyhlásit válečný stav, aniž by čekal na rozhodnutí parlamentu. Obdobně ústava Litevské republiky z 25. ř́jna 1992 ve svém čl. 142 odst. 2. Podobně ústava Lotyšské republiky ze dne 15. února 1922 a znovu vyhlášená 6. června 1993 ve svém oddíle III., bodu 44. Abychom však opustili oblast pobaltskou, můžeme čerpat z př́íkladu ústavy Rumunské republiky ze dne 21. listopadu 1991, konkrétně jejího čl. 92 odst. 3. Svěření pravomoci vyhlašovat mimořádné právní stavy prezidentu republiky nepřekvapí v prŕípadě Ruské federace, jejíž ústava z 12. prosince 1993 tuto záležitost upravuje v čl. 87. Ústava Albánské republiky z 28. listopadu 1998 tuto pravomoc zakládá v čl. 162 odst. 1. Běloruský prezident tak činí na základě čl. 84 odst. 29 ústavy z 15. března 1994. Bulharský prezident je vybaven takovou pravomocí na základě čl. 100 odst. 5 ústavy z 12. července 1991. Obdobné řešení volí také ústava Makedonské republiky ze 17. listopadu 1991 v čl. 124 odst. 3. Obdobně v př́ípadě Slovinska, jehož ústava z 23. prosince 1991 náhradní mechanismus vyhlášení mimořádných právních stavů a užití ozbrojených sil obsahuje v čl. 92.

Podobná řešení však neobsahují pouze ústavy států střední a východní Evropy. Silná role prezidenta republiky nepřekvapí ve Francii, kde tuto záležitost řeší ústava ze 4. října 1958 ve svém čl. 16. Nicméně i německá spolková ústava z 23 . května 1949 , ačkoliv počitá velmi silně se schválením mimořádných opatření Spolkovým sněmem a Spolkovou radou, předpokládá pro případ obtíží s jeho svoláním přijetí rozhodnutí Společnému výboru. Také nizozemská ústava ze 17. února 1983 ve svém čl. 100 počítá s nasazením ozbrojených sil z rozhodnutí vlády (v mezích zákona) a se souhlasem parlamentu, ale tehdy, kdy by předběžný souhlas nebyl možný, se počitá s projednáním následným. Také italská ústava z 22. prosince 1947 počitá ve svém čl. 77 odst. 2 s možností vlády v př́ípadě nutnosti vydávat dekrety se silou zákona, které musí být následně schváleny parlamentem.

Z nových ústav lze odkázat na Finskou republiku a její ústavu z 11. června 1999. Její čl. 23 stanoví, že mimořádné právní stavy jsou vyhlašovány vládním dekretem, který je následně předkládán parlamentu ke schválení. Dále ačkoliv Finové učinili velký posun od systému poloprezidentského k systému parlamentnímu, v čl. 129 své ústavy stanoví, že mobilizaci ozbrojených sil vyhlašuje prezident republiky na návrh vlády. Obdobně švýcarská ústava z 18. dubna 1999 svěřující v čl. 185 mobilizaci ozbrojených sil Federální radě a následné posouzení Federálnímu shromáždění. Podobně můžeme ukázat na Mad’arskou republiku a její ústavu z 25. dubna 2011, která počítá se svěřením pravomoci vyhlásit nutná opatření $\mathrm{k}$ odvrácení agrese prezidentu republiky ve svém čl. 48 odst. 3 . 
stavu prezidentem republiky na návrh vlády s tím, že parlament by takové opatření při nejbližší př́ležitosti potvrdil, a pokud by se tak nestalo, došlo by k jeho okamžitému zrušení.

\section{3. ÚSTAVNÍ MECHANISMUS POVOLOVÁNÍ PŘELETU゚ PŘES ÚZEMÍ ČESKÉ REPUBLIKY A JEHO NEREALIZOVATELNOST}

Při dalším hodnocení podoby čl. 43 Ústavy lze říci, že jeho novela provedená ústavním zákonem č. 300/2000 Sb. byla v zásadě zdařilá. Užitečné a funkční je zakotvení zvláštního mechanismu schvalování účasti České republiky v obranných systémech mezinárodní organizace, jíž je Česká republika členem. Stejně tak vhodné a v zásadě funkční je základní rozdělení vyslovování souhlasu s vysláním vlastních ozbrojených sil mimo území státu a povolení př́itomnosti cizích ozbrojených sil na území státu mezi parlament a vládu podle účelu takové akce, respektive dle její délky a dalších podmínek jejího provedení. Těmto věcem není dle mého názoru nutné věnovat pozornost, s určitými výjimkami týkajícími se věcí Ústavou nyní neřešených a vyplývajících z vývoje za posledních 16 let, jimž budu věnovat pozornost dále.

Z hlediska stávající ústavní úpravy však je nutno věnovat pozornost mechanismu povolování především přeletů přes území České republiky. Jak ukáži dále, je stávající ústavní úprava nefunkční.

Povolování přeletů - průjezdy v zásadě nejsou či nemusí být problematické, nebot’ jejich počet je menší a lze je plánovat s větším předstihem - přes území České republiky je regulováno čl. 43 odst. 5 písm. a) a odst. 6 Ústavy. Rozhodovací pravomoc je svěřena vládě, viz odst. 5 , nicméně podle odst. 6 je vláda povinna neprodleně informovat obě komory parlamentu, přičemž parlament může rozhodnutí vlády zrušit. Ke zrušení postačí nesouhlas jedné komory vyslovený nadpoloviční většinou všech členů komory.

Ústavní text lze dle mého názoru interpretovat jediným způsobem. Vláda je povinna informovat parlament neprodleně, ${ }^{15}$ a to tak, aby parlament měl možnost rozhodnutí posoudit a případně zrušit, a to ještě před jeho naplněním. Tento závěr vyplývá hned ze dvou argumentů. V prvé řadě by nedávalo smysl, aby si ústavodárce př́l, aby parlament rozhodoval a eventuálně rušil již zkonzumovaná rozhodnutí. V druhé řadě zde je argument kontrolní funkce parlamentu nad činností vlády. Prvý uvedený argument považuji za rozhodující, protože opačný výklad vede k absurdním závěrům.

Potíž však spočívá v tom, že uvedený ústavní mechanismus prakticky nelze dodržet. Důvodem je velmi vysoký počet přeletů nad územím České republiky. Analýza ${ }^{16}$ připra-

Neměli bychom ovšem zapomínat na nám blízkou ústavu Slovenské republiky z 1. září 1992, která svěruje ve svém čl. 102 odst. 1 písm. m) pravomoc vyhlašovat mimořádné právní stavy a mobilizaci, po návrhu vlády, prezidentu republiky.

Podobně by bylo možné pokračovat ještě dlouho. Lze každopádně shrnout, že náhradní způsob vyhlašování mimořádných právních stavů, respektive činění rozhodnutí $\mathrm{k}$ jejich odvrácení, není v evropských ústavách řešením neznámým, ani nijak výjimečným.

15 Význam pojmu „neprodleně“ sice politici s oblibou zpochybňují či relativizují, ale nevyžaduje žádný zvláštní výklad. Vláda má jednat bez jakékoliv prodlevy, tedy nemá předání informace zdržovat či je odkládat.

16 Celý název dokumentu je „Analýza stávající právní úpravy dosavadní praxe vyslovování souhlasu s přelety a průjezdy ozbrojených sil jiných států přes území České republiky“. 
vená ministerstvem obrany pro jednání vlády ${ }^{17}$ uvádí, že počet přeletů nad územím státu činí 500-700 měsíčně, přičemž většina byla partnerským státem vyžadována nebo oznamována velmi krátkou dobu před uskutečněním, obvykle méně než 7 dní. Ministerstvo dále uvádí, že některé požadavky na přelety, zejména $v$ krizových situacích spočívajících např̀. v náhlé nutnosti evakuace ozbrojených sil nebo obyvatelstva nebo v přepravě raněných, jsou předkládány dokonce pouze několik hodin před uskutečněním letu.

Příčin těchto vysokých počtů přeletů přes území České republiky je několik, jistě mezi ně patř́ zeměpisná poloha našeho státu, ale také naše členství v různých mezinárodních organizacích, na prvním místě v Severoatlantické alianci, a z nich vyplývající spojenecké závazky.

Současně je nutno uvést, že sama Česká republika má obdobné zájmy jako její spojenci či zahraniční partneři a nastávají situace, kdy je třeba evakuovat české státní občany ze zahraničí ${ }^{18}$ nebo zraněné př́islušníky Armády České republiky, ${ }^{19}$ respektive české jednotky v zahraničí vyměňovat a zásobovat.

To znamená, že je nutno počítat mj. s principy reciprocity a spojenectví, na jejichž fungování má Česká republika jednoznačný zájem. Ačkoliv princip reciprocity neplatí automaticky a bezvýjimečně, přesto jeho dodržování má vliv na rozhodování v jednotlivých př́padech. Stejně princip spojenectví znamená, že Česká republika by svou rozhodovací praxí a jejími mechanismy neměla znejišt'ovat spojence, např. rozhodnutím těsně před uskutečněním přeletu.

Jak je s ohledem na výše uvedené patrno, Ústavou definovaný mechanismus rozhodování nelze $\mathrm{v}$ praxi naplnit. $\mathrm{V}$ př́padě některých náhlých situací vyžadujících okamžitou reakci $v$ řádu hodin je téměř vyloučené získat i jen souhlas vlády, natož projednání v parlamentu.

V praxi je postupováno podle mechanismu, který navrhlo na přelomu tisíciletí ministerstvo obrany. Na každý rok je vypracován seznam států, jejichž ozbrojeným silám je za účelem průjezdů či přeletů přes území České republiky vydán souhlas vládou na dobu jednoho roku. $\mathrm{V}$ př́padě ostatních států je postupováno ad hoc. O uskutečněných průjezdech a přeletech je potom informován parlament. A to v některých letech v půlroční frekvenci, v některých letech se jednalo o frekvenci čtvrtletní. Poprvé bylo tímto způsobem postupováno v roce 2001, konkrétně se jednalo o usnesení vlády č. 1322 z 10. prosince 2001. Podobně bylo postupováno v dalších letech až do dneška.

Pokud se jedná o státy, které byly zahrnuty do výše uvedené prvé skupiny, jednalo se o členské státy NATO a účastníky Partnerství pro mír. Nicméně toto rozdělení se ukázalo být nevyhovující, protože skupina států, viči nimž bylo postupováno ad hoc byla velmi velká a řada států byla pro Českou republiku důležitá $\mathrm{z}$ hlediska jejich polohy pro realizaci zájmů našeho státu. Takto došlo $\mathrm{k}$ postupnému rozš́í̌ení prvé skupiny a v roce 2015 do ní náleží 84 států a do skupiny druhé potom 117 států. ${ }^{20}$

17 Projednána vládou dne 22. července 2015 jako dokument č. j. 875/15 a vzata na vědomí usnesením vlády č. $580 \mathrm{z}$ téhož dne.

18 Jednalo se např. o evakuaci českých státních občanů postižených vlnou tsunami z Thajska v roce 2004.

19 Zde se v posledních letech jednalo zejména o evakuace z Afghánistánu.

20 Dopočítáno do čísla 201, což je počet států, které Česká republika v polovině roku 2015 uznávala. 
Za účelem realizace popsaného mechanismu byla na základě usnesení Bezpečnostní rady státu č. 136 z 20. listopadu 2000 uzavřena Dohoda o povolování letů státních letadel (dále jen „Dohoda“). Aktuální verze Dohody byla uzavřena dne 27. záŕí 2004 na základě usnesení Bezpečnostní rady státu č. 130 ze dne 13. července 2004. Dohoda je uzavřena mezi ministerstvy obrany, vnitra, financí, dopravy a zahraničních věcí. Zabezpečováním přeletů ozbrojených sil jiných států je pověřeno ministerstvo obrany, které tak činí prostřednictvím Odboru vojenské dopravy. Vyslovení vládního souhlasu na dobu jednoho roku tedy není časově a co do počtu neomezeným povolením pro přelety letadel států zahrnutých do prvé skupiny, ale předpokladem pro rychlé a snadné vyř́izení povolení $\mathrm{k}$ jednotlivému přeletu. Na něm se podílejí v mezích svých kompetencí všechna výše uvedená ministerstva.

Nicméně ani tato praxe se neukázala být jako dostačující pro povolování přeletů států náležejících do druhé skupiny. Současně, jak již bylo uvedeno výše, princip reciprocity bránil operativnímu přístupu partnerského státu v př́padě, když jej neuplatňovala Česká republika, a přitom to pro Českou republiku mohlo být zásadní.

Proto ministerstvo obrany navrhlo vládě v roce 2007 nový mechanismus, který spočíval ve vyslovení vládního souhlasu předem všem Českou republikou uznávaným státům $\mathrm{k}$ přeletům na jeden rok, ovšem $\mathrm{s}$ tím, že státy budou i nadále děleny na dvě výše uvedené skupiny. V př́padě prvém bude povolení $\mathrm{k}$ jednotlivému přeletu vydávat bez dalšího Odbor vojenské dopravy, v případě druhém také, avšak za splnění dalších podmínek, kterými jsou: absence námitek ministerstva zahraničních věcí proti uskutečnění daného letu, povolení může mít pouze jednorázový charakter a platnost pouze na 72 hodin, a každé takto vydané povolení bude zvláště vyznačeno ve zprávě pro parlament. ${ }^{21}$ Tento postup byl vládou poprvé schválen dne 19. prosince 2007 usnesením č. 1437. Obdobně bylo postupováno i v následujících letech.

Jak je patrné, povolování a uskutečňování přeletů cizích ozbrojených sil přes území České republiky je velmi rozsáhlou a náročnou záležitostí a praxe několikrát narazila na meze tehdejších postupů a pravidel, která musela být změněna. Současně je zřejmé, že existující ústavní úprava je nerealizovatelná. Ačkoliv výše uvedená Analýza tvrdí, že stávající praxe je v souladu s ústavním pořádkem, z důvodů, které jsem uvedl podrobně výše, s tímto závěrem nesouhlasím.

Zastávám názor, že ústavní mechanismus povolování přeletů cizích ozbrojených sil přes území České republiky by měl být změněn. Vzhledem k tomu, že v případě kritických okolností není dostatečně operativní ani vyslovení souhlasu vládou, domnívám se, že Ústava by měla být změněna a měla by dát vládě možnost určit pravidla povolování přeletů. Současně by mělo dojít k přeformulování kontrolní pravomoci parlamentu, který by mohl posuzovat vládou stanovená pravidla povolování přeletů. Takto by mohla být existující praxe, která je vyhovující, východiskem pro úpravu ústavního pořádku. ${ }^{22}$

21 Přeletů ozbrojených sil států druhé skupiny je velmi málo. Nejvíce jich bylo 10 za rok, a to v roce 2008 . V roce 2009 se jednalo o 2 přelety, v roce 2010 o 5 přeletů, v roce 2011 o 1 přelet, v letech 2012-2014 vždy o 2 přelety za rok. Zdrojem těchto údajů je výše uvedená Analýza.

22 Přirozeně by bylo možné se pokusit dále rozlišit přelety letadel přepravujících např. cizí ústavní činitele nebo zraněné vojáky od přeletů např. bombardovacích svazů. Je ale otázkou, zda lze v ústavním textu takové rozlišení provést. Současná praxe se přitom ukazuje být v zásadě vyhovující a z postoje parlamentu není 


\section{K OTÁZCE ÚSTAVNÍHO POSTUPU PŘI PŘÍPADNÉM ZŘIZOVÁNÍ CIZÍ STÁLÉ VOJENSKÉ ZÁKLADNY NA ÚZEMÍ ČESKÉ REPUBLIKY}

V minulých letech se objevila úvaha o možném zřízení stálé vojenské základny cizího státu na území České republiky. Politická diskuze o této otázce byla poměrně bouřlivá, ale $\mathrm{v}$ jejím rámci nebyla podrobněji probrána otázka, jakým ústavní postup by měl být při eventuálním povolování a zřizování takové vojenské základny zvolen.

Mám za to, že se jedná o záležitost ústavního charakteru. V prvé řadě proto, že tato problematika souvisí $\mathrm{v}$ té nejširší možné míře $\mathrm{s}$ otázkami nakládání s vlastními i cizími ozbrojenými silami. V druhé řadě jde o záležitost dotýkající se velmi úzce suverenity státu. Tyto záležitosti na tomto místě nebudu podrobněji rozebírat, nebot' jsem tak učinil již dříve. ${ }^{23}$

Nabízí se několik otázek, jejichž zodpovězení není jednoznačné ani jasné, a tím pádem není jasný ani vhodný ústavní postup. Samotných postupů při realizaci dlouhodobého pobytu cizích ozbrojených sil na území České republiky může být více. Může být nejprve projednán a realizován na základě mezinárodní smlouvy, která by stanovila bližší podmínky pobytu. Teprve poté a $\mathrm{v}$ rámci této mezinárodní smlouvy může dojít $\mathrm{k}$ přsunu na území státu. Jemu by patrně měl předcházet souhlas parlamentu, př́ípadně předcházený souhlasem vlády, dle čl. 43 Ústavy. Lze si však představit také situaci, že nejprve dojde $\mathrm{k}$ přsunu, přirozeně na základě souhlasu parlamentu, kterému opět může předcházet souhlas vlády, přičemž cizí jednotky by se nejprve v rámci svého pobytu řídily výše uvedeným zákonem č. 310/1999 Sb. A teprve později by došlo k uzavření mezinárodní smlouvy, která by stanovila podrobnější nebo odchylné podmínky od zákona. ${ }^{24}$ Otevřená je také otázka charakteru př́ípadné mezinárodní smlouvy stanovící právní režim cizí vojenské základny na území České republiky.

Krátce lze říci, že čl. 43 Ústavy spolu s dalšími jejími ustanoveními zřízení stálé vojenské základny cizí moci na našem území umožňují, ale některé otázky lze pokládat za sporné.

Na prvém místě je vhodné věnovat pozornost otázce, jaký charakter by měla mezinárodní smlouva stanovící právní režim cizí vojenské základny a jejího osazenstva. Nabízejí se dvě možnosti, podle okolností.

patrný názor, že by vláda konala z věcného a politického hlediska nesprávně. Proto je patrně bez většího nebezpečí svěření určení celkového mechanismu do rukou vlády.

23 KUDRNA, J.: K některým otázkám interpretace čl. 43 Ústavy. In JIRÁSKOVÁ, V. (ed.): Interpretace Ústavy České republiky a Ústavy Slovenské republiky (Evropeizace ústavních systémů). Praha: UK Právnická fakulta, 2007.

$24 \mathrm{~S}$ ohledem na požadavek právní jistoty a předvídatelnosti práva se kloním ke stanovisku, že za běžné bezpečnostní situace by měla být nejprve řádně sjednána, ratifikována a vyhlášena př́slušná mezinárodní smlouva, včetně vyslovení souhlasu s ratifikací oběma komorami Parlamentu, a teprve poté by měl Parlament, se znalostí sjednaného právního rámce, rozhodovat o udělení souhlasu k pobytu cizích ozbrojených sil na území České republiky. Nevylučuji však možnost opačného pořadí v př́ípadě akutního ohrožení bezpečnosti státu. Za vyloučené však považuji, aby byl souhlas k pobytu vyjádřen přímo v mezinárodní smlouvě a oba stupně schvalování se tak spojily v jeden. Není to totiž Parlament, kdo smlouvu sjednává a uzavírá na straně jedné, a na straně druhé vláda či prezident nemůže souhlas Parlamentu zaručit a učinit $\mathrm{z}$ něj předmět smlouvy. 
Může se jednat o smlouvu spojeneckou, jak s ní počítá čl. 49 písm. b) Ústavy. K její ratifikaci tak bude třeba souhlasu obou komor Parlamentu, a to nadpoloviční většinou přítomných členů každé komory, při splnění podmínky usnášeníschopnosti.

Avšak s největší pravděpodobností by smlouva o zrrízení cizí vojenské základny na území České republiky zahrnovala jisté prvky jurisdikčních výsad a exempcí, zejména pokud se jedná o disciplinární, eventuálně trestní a přestupkovou jurisdikci nad cizími vojáky. Bývá častým ujednáním v takových smlouvách, že hostitelský stát se ve větším nebo menším rozsahu vzdává své jurisdikce, čímž omezuje svou svrchovanost a přenáší část svých pravomocí na stát, jehož vojáky hostí. $\mathrm{V}$ takovém případě by se však jednalo o smlouvu podle čl. 10a Ústavy. K jejímu schválení by potom byla potřebná ústavní většina.

Svůj význam může mít také skutečnost, že parlament nemusí být jediným fórem, kde by tato otázka mohla být posuzována. Charakter př́slušné mezinárodní smlouvy by mohl být také přezkoumáván Ústavním soudem, na který se může obrátit také menšina poslanců či senátorů.

Dalším krokem bude vyslovení souhlasu Parlamentu s pobytem cizích ozbrojených sil na území České republiky. Jak jsem uvedl výše, mám za to, že ten nemůže být zakotven v samotné mezinárodní smlouvě. Vysloven musí být nadpoloviční většinou všech členů každé z komor Parlamentu.

Na tomto místě je vhodné upozornit, že Ústavou požadovaná většina pro toto druhé hlasování, je vy̌šsí, než v př́padě vyslovování souhlasu se smlouvou podle čl. 49 písm. b). Logika věci by žádala, aby kvalifikovaná, respektive nejvyšší většina byla vyžadována $\mathrm{v}$ př́ípadě hlasování prvého. $\mathrm{V}$ případě, že by smlouva o zřízení stálé vojenské základny svým obsahem nespadala režimu čl. 10a Ústavy, potom by se náročnost podmínek stupňovala. Komplikovalo by se nikoliv sjednání smlouvy, ale její naplnění. Potenciálně zde mohou vzniknout poměrně vážné problémy se splněním závazků České republiky v př́ípadě, kdy se změní rozložení sil mezi zastánci a odpůrci smlouvy v jedné z komor mezi prvním a druhým hlasováním. ${ }^{25}$ Takový důsledek současné ústavní úpravy je nežádoucí.

V případě, kdy by byla smlouva o zrízení cizí vojenské základny klasifikována jako smlouva dle čl. 10a Ústavy, tyto problémy odpadají.

Tyto otázky by podle mého názoru měly být jasně vyřešeny předtím, než dojde k př́ipadné potřebě realizovat popsané řešení, které lze předpokládat spíše v situaci krizové a vyhrocené. Za takových okolností není vhodné řešit základní sporné otázky, ale spíše rychle jednat.

Otevřenou otázkou také je forma, respektive podrobnost souhlasu s pobytem cizích ozbrojených sil, který vysloví Parlament. V takto závažném př́padě by bylo krajně nevhodné, aby byla převzata praxe schvalování zejména přeletů nad územím státu, kdy se tak činí často formou obecného rozhodnutí. Souhlas s pobytem by měl být dostatečně konkrétní zejména co do alespoň rámcového určení počtu př́ílušníků ozbrojených sil,

25 Tuto situaci nelze vyloučit, protože nebude-li podpora zř́zení základny ve společnosti a v Parlamentu dostatečně přesvědčivá, lze očekávat větší odpor při jednání o schválení př́sunu konkrétních lidí a prostředků, než při dřívějším jednání o smlouvě, která je pro většinu veřejnosti, v porovnání s př́ísunem jednotek, relativně abstraktní záležitostí. 
druhu vojenských jednotek a způsobu jejich vybavení. Pouze za těchto tří podmínek splní Parlament svou kontrolní roli. Současně podle mého názoru platí také to, že podstatná změna počtu nebo druhu př́tomných vojenských jednotek nad předchozí souhlas nebo mimo jeho rozsah by vyžadovala nový souhlas parlamentu. Také $v$ tomto př́ípadě hrozí eventuální zablokování v parlamentu.

Jak je z uvedeného patrné, zastávám názor, že v rámci stávající ústavní úpravy cizí základnu na území České republiky zř́idit lze. Současně se však domnívám, že v souvislosti s touto záležitostí se může objevit celá řada sporných otázek, at' už povahy teoretické nebo praktické. Vzhledem $\mathrm{k}$ tomu, že uvedené opatření by bylo poměrně citlivou záležitostí a uskutečňováno by bylo spíše $\mathrm{v}$ situaci vážné krize, a mohlo by být předmětem přezkumu Ústavního soudu, měla by podle mého názoru existovat shoda co do postupu a jeho jasná pravidla daleko dříve.

\section{K NĚKTERÝM LIMITU゚M SOUČASNÉ ÚSTAVNÍ ÚPRAVY PRO PŘÍPAD ROZŠÍŘENÍ ÚLOHY NATO}

NATO již v roce 2002, na svém summitu konaném v Praze, rozhodlo o zř́izení Sil rychlé reakce (NATO Response Forces, dále jen „NRF“). O dva roky později bylo oznámeno dosažení jejich operační způsobilosti. NRF mají mít způsobilost zasáhnout kdekoliv na světě a plnit různé úkoly, včetně civilní ochrany, mírových operací nebo použití síly. Jedná se o mnohonárodnostní jednotky ustavované na základě rotačního principu. Tedy každý členský stát účastnící se na činnosti NRF poskytuje část svých ozbrojených sil pod velení NATO. ${ }^{26}$ Na svém summitu konaném v roce 2014 ve Walesu NATO rozhodlo o vytvoření Sil velmi rychlé reakce (NATO Very High Readiness Joint Task Force, dále jen „VJTF“). ${ }^{27}$ Akceschopnost této části NRF má být ještě vyšší, počitá se $\mathrm{s}$ jejich nasazením během 48-72 hodin.

Z hlediska české ústavní úpravy můžeme při plnění svých závazků vůči NATO v závislosti na úkolu, který by měly zejména VJTF plnit, narazit na zásadní limity. Mise NRF i VJTF znamená vyslání ozbrojených sil České republiky mimo území státu. Takový krok je, podle okolností, podmíněn bud' souhlasem parlamentu, nebo ve vyjmenovaných prípadech vlády.

Rozhodování parlamentu nemusí být dostatečně pružné zejména pro činnost VJTF a jejich vysokou akceschopnost a pružnost nasazení, s nimiž je počítáno. Dokonce i pro vládu může obtížné splnit být limit 48-72 hodin, což je pro některé typy jednotek limit maximální, nikoliv žádoucí. Každopádně vláda má v tomto směru vyšší předpoklady se sejít a rozhodnout.

Vláda je však limitována jasně stanovenými ústavními podmínkami, kdy může rozhodovat namísto parlamentu. Je otázkou, zda některé mise, $\mathrm{k}$ nimž by mohly VJTF být určeny, nepřesahují tyto meze. Omezující by mohlo být ustanovení čl. 43 odst. 4 písm. b), které předpokládá souhlas přijímajícího státu. Pokud by měla být předpokládána mírová operace VJTF bez souhlasu prijímajícího státu, potom by z hlediska naší

26 Více viz např. zde: http://www.natoaktual.cz/nrf-cke-/na_zpravy.aspx?y=na_summit/nrf_main.htm [cit. 20. 10. 2016].

27 Více viz např. zde: http://www.nato.int/cps/pl/natohq/topics_49755.htm [cit. 20. 10. 2016]. 
Ústavy byl vyžadován souhlas parlamentu. Může také nastat situace podobného zásahu v oblasti tzv. zhrouceného státu, kde souhlas nemá ani kdo dát. I v tomto př́ípadě by však účast našich ozbrojených sil na misi VJTF zřejmě byla podmíněna souhlasem parlamentu.

Souhlas parlamentu zajištuje jednak vyšší kontrolu, ale zejména vyšší legitimitu rozhodnutí, které ve svých důsledcích má závažné mezinárodní dopady, a to jak politické, tak i právní. Na druhé straně však může nastat situace, že Česká republika nebude reálně schopna naplnit své závazky vůči NATO.

Tato otázka by dle mého názoru měla být šiřreji diskutována, a i zde se nabízí prostor k úpravě Ústavy. Současně však zastávám názor, že se jedná o záležitost vysoce citlivou a potenciálně spornou, protože mnohé ${ }^{28}$ zásahy na území cizího státu bez mandátu OSN hrozí porušením Charty OSN, konkrétně zásady nevměšování se do vnitřních poměrů členského státu. $\mathrm{O}$ to by měla být př́padná diskuze důkladnější.

\section{ZÁVĚREČNÉ SHRNUTÍ}

Jak jsem v podrobnostech uvedl již výše, dle mého názoru obsahuje současná ústavní úprava bezpečnostních otázek celou řadu nedostatků, a to jak v záležitosti koncepce, tak i konkrétních ustanovení.

Na prvém místě stávající ústavní úprava dává velké pole působnosti a málo záruk v oblasti omezování lidských práv a svobod. Značný prostor je dán zákonodárci, což neodpovídá myšlence konstitucionalismu. $\mathrm{V}$ tomto směru by tedy mohla být ústavní úprava detailnější, aby bylo zrèejmé, za jakých okolností může být do ústavně garantovaných práv a svobod zasaženo. Může se to týkat např. řady práv ze skupiny práv na soudní a jinou právní ochranu. $V$ tomto př́padě není dostatečným způsobem naplněna již dřive popsaná zásada konstitucionalizace mimořádných právních stavů.

Druhou oblastí zasluhující změnu je dle mého názoru úprava vyhlašování zejména válečného stavu a určitého vyjasnění, co je válečným stavem rozuměno. Pokud se jedná o jeho vyhlašování, je možné uvažovat o možnosti jeho vyhlášení náhradním způsobem. Ten by měl být stanoven pro prípad, kdy by bylo vyhlášení parlamentem nerealizovatelné. Např. proto, že by se parlament nemohl sejít z důvodu probíhající nebo bezprostředně hrozící agrese. Zde narážíme nejenom na nejasnost, ale i na nepružnost celé řady klíčových procedur. $Z$ hlediska teoretického narážíme na problém s naplněním zásady diferenciace, respektive proporcionalizace mimořádných právních stavů. Problémem je také př́lišná parlamentarizace.

Obdobná situace nastává u třetího velkého problému, a sice mechanismu schvalování přeletů cizích ozbrojených sil nad územím České republiky. Stávající ústavní

${ }_{28}$ Mezinárodní právo veřejné např. nepovažuje za nelegální použití síly za účelem ochrany vlastních občanů na území cizího státu i bez jeho souhlasu. Viz napřs. SHAW, M. N.: International Law. Cambridge: Cambridge University Press, 2008, s. 1143-1146. Pokud by bylo zvažováno vyslání českých vojenských jednotek na území cizího státu za účelem např. záchrany českých státních občanů, otázka souladu či nesouladu s mezinárodním právem veřejným by žrejmě nevyvstala. Zůstal by však zachován problém vyplývající z ústavní úpravy, podle které by souhlas s podobným vysláním nemohla vyslovit pouze vláda, ale musel by tak učinit parlament. Taková procedura je jednak časově náročná a existuje zde větší hrozba vyzrazení. 
procedura je nerealizovatelná. Podle mého názoru by Ústava měl dát pravomoc stanovit pravidla pro povolování takových přeletů vládě, která by tak činila v určitém zákonném rámci. Také zde narážíme na př́lišnou parlamentarizaci.

Čtvrtou otázkou, která by zasluhovala zvláštní řešení, je procedura, na jejímž základě by př́ípadně byla zřízena cizí vojenská základna na území České republiky. Stávající ústavní úprava takový krok umožňuje. Přitom ale hrozí opět řada nejasností a hrozeb zdržení.

Pátou oblastí zasluhující určité zpružnění a vyjasnění je zapojení České republiky do Sil rychlé reakce NATO. Je otázkou, nakolik by mělo dojít k uvolnění schvalovacích procedur, ale současně je zřejmé, že stávající Ústava patrně není s to dostát požadavkům vyplývajícím $z$ našich spojeneckých závazků. $V$ této věci by byla zvláště na místě důkladná odborná a politická diskuze, jejímž předmětem by byl rozsah spojeneckých závazků České republiky a jejich možné mezinárodněprávní důsledky, a tomu potom odpovídající způsoby naplňování uvedených závazků, včetně schvalovacích mechanismů.

Celá výše popsaná situace je o to závažnější, že se nejedná o doporučení směřující pouze k určitému vylepšení či racionalizaci procedur. Podstatná část identifikovaných problémů dle mého názoru brání řádnému fungování státu v krizových situacích v souladu s ústavními předpisy, nebo tím přinejmenším hrozí. Jiné se mohou velmi úzce dotýkat základních zásad mezinárodního práva veřejného a pravidel fungování mezinárodního společenství.

Na úplný závěr lze shrnout, že v rámci stávajícího ústavního uspořádání České republiky je oprávněn přijmout téměř jakékoliv rozhodnutí ve věci zajišt'ování bezpečnosti státu parlament. Jediným limitem jeho rozhodování je čl. 1 odst. 2 Ústavy. Rozhodnutí parlamentu by tedy nemělo porušovat závazky vyplývající České republice z mezinárodního práva. Parlamentarizace takového rozhodování zajišt’uje nejvyšší legitimitu činěných rozhodnutí, a také kontrolu nad výkonnou moci. Současně však je nutno říci, že rozhodování parlamentu může být těžkopádné a jeho časová náročnost může být v př́mém rozporu s některými mezinárodními závazky České republiky. V některých prípadech podobný problém může patrně vyvstat i v př́padě vlády. $V$ př́padě parlamentu také existuje větší nebezpečí vyzrazení projednávané záležitosti.

Ústava České republiky v tomto směru vyžaduje dle mého názoru přehodnocení. Je pro to ideální čas, protože na jedné straně jsou poměrně jasné potřeby a nedostatky, na straně druhé je relativně čas na rozvážnou úvahu a prípadnou změnu.

JUDr. Jan Kudrna, Ph.D.

Univerzita Karlova, Právnická fakulta

kudrnaj@prf.cuni.cz 